\title{
Genologia lingwistyczna a badania nad komentarzem e-sportowym (problemy metodologiczne)
}

\section{Wprowadzenie}

Współczesna nauka coraz częściej zajmuje się rozwojem i funkcjonowaniem gier komputerowych. Obecnie dzięki grom można nie tylko spędzać wolny czas, lecz także realizować sportowe (czy raczej e-sportowe) ambicje, osiągać sukcesy w przestrzeni internetowej, na przykład prowadząc kanał w portalu YouTube, i w ten sposób zarabiać na swoje utrzymanie. Rozwój gier komputerowych z gatunków takich jak RTS, FPS czy MOBA spowodował również powstanie międzynarodowej sceny e-sportowej. Gracz, który osiągnął poziom mistrzowski, może stać się członkiem profesjonalnej drużyny i na co dzień trenować swoje umiejętności, by później zaprezentować je na turniejach, takich jak Major czy Intel Extreme Masters ${ }^{1}$. Wygrana w największych wydarzeniach tego typu wiąże się z nagrodą rzędu kilkuset tysięcy euro. Celem moich badań nad grami komputerowymi jest opis genologiczny komentarza e-sportowego na przykładzie komentarzy do meczów gry Counter Strike: Global Offensive.

Swoje rozważania rozpocznę od charakterystyki gry Counter Strike: Global Offensive oraz zjawisk komunikacyjnych, jakie zaistniały dzięki rozwojowi wymienionych przeze mnie powyżej gatunków gier i tym samym stworzyły nowe perspektywy badawcze dla językoznawców. Dalej przedstawię wybrane metody badawcze z zakresu

1 Dwa największe międzynarodowe turnieje w grach komputerowych takich jak Counter Strike: Global Offensive czy League of Legends. 
genologii lingwistycznej, ze szczególnym uwzględnieniem propozycji Marii Wojtak. Następnie krótko zreferuję wyniki badań Beaty Grochali nad komentarzem sportowym, w których badaczka wykorzystała metodologię Wojtak. Ostatnia część artykułu będzie poświęcona analizie genologicznej komentarza e-sportowego na przykładzie gry Counter Strike: Global Offensive.

\section{Podstawowe informacje o grze Counter Strike: Global Offensive}

Counter Strike (dalej skrót: CS) to jedna z najpopularniejszych w Polsce gier sieciowych typu first-person shooter. Rozgrywka toczy się na jednej z kilkunastu dostępnych dla graczy „map” - wirtualnych plansz. Uczestnicy mają do wyboru różne tryby gry, m.in. klasyczny tryb turniejowy, wyścig zbrojeń czy tzw. demolkę. W artykule ograniczę się do krótkiego opisu trybu turniejowego, który stanowi podstawę rozgrywek e-sportowych w CS-a, więc jest dla mnie, jako badacza komentarza e-sportowego, najistotniejszy.

Mecz rozgrywany w trybie turniejowym trwa 30 rund. Gracze są podzieleni na dwie drużyny, których członkowie odgrywają w świecie gry role terrorystów i antyterrorystów. Po piętnastu rundach gracze wymieniają się rolami („terroryści” stają się „antyterrorystami” i odwrotnie). W każdej rundzie zadaniem jednej drużyny jest podłożenie bomby w określonym miejscu na mapie i doprowadzenie do detonacji ładunku, drugiej - niedopuszczenie do tego (przez rozbrojenie bomby lub zabicie wszystkich wirtualnych przeciwników). Mecz zwycięża drużyna, która wygra 16 rund. W tradycyjnej rozgrywce możliwy jest remis, jednak w decydujących etapach turniejowych (na przykład w półfinale, kiedy tylko jeden zespół może awansować do finału) gra toczy się do uzyskania przez jedną z drużyn dwupunktowej przewagi, podobnie jak podczas meczów piłki siatkowej, kiedy przewaga dwu punktów jest konieczna do zwycięstwa. Innym podobieństwem do tradycyjnych gier zespołowych jest zamiana ról po piętnastu rundach, która przypomina zmianę stron po pierwszej połowie meczu piłki nożnej. Takie analogie świadczą o istnieniu pewnych podobieństw między komentarzem sportowym (np. do meczów piłki nożnej) a e-sportowym (np. do meczów CS), które przybliżę w dalszej części artykułu.

Podczas meczu gracze komunikują się ze sobą przez komunikator głosowy, co pozwala im konsultować kolejne ruchy, taktykę, czy ostrzegać się wzajemnie przed działaniami drużyny przeciwnej. Konieczność porozumiewania się doprowadziła do powstania socjolektu graczy CS, co stanowi kolejną przestrzeń do badań lingwistycznych.

Na popularność gry Counter Strike: Global Offensive w Polsce prawdopodobnie wpłynęła i wciąż wpływa obecność na scenie e-sportowej polskiej drużyny Virtus. pro. Wraz z kolejnymi jej sukcesami na arenie międzynarodowej mecze z udziałem Virtus.pro w internecie oglądały coraz większe rzesze kibiców. Zaistniała więc po- 
trzeba komentowania wydarzeń obserwowanych przez widzów na ekranie. Miało to niewątpliwie wpływ na rozwój powstającego dopiero w Polsce nowego gatunku medialnego, jakim jest komentarz e-sportowy. Komentowane rozgrywki możemy obserwować w internecie przede wszystkim w portalu Twitch.tv oraz na niektórych kanałach w serwisie YouTube. Specyfikę i różnice w komentowaniu w poszczególnych portalach opiszę poniżej. Najpopularniejszym polskim komentatorem meczów CS jest Piotr „Izak” Skowyrski, którego komentarze stanowią podstawę materiałową analizy przedstawionej w dalszej części artykułu. Sylwetkę tego komentatora opiszę poniżej, $\mathrm{w}$ rozdziale dotyczącym analizy aspektu pragmatycznego komentarza e-sportowego.

\section{Nowe zjawiska - nowe wyzwania badawcze}

Gry komputerowe, e-sport, mecze, turnieje, komentarze to nowe zjawiska komunikacyjne, społeczne i kulturowe. Zaczynają wywierać coraz większy wpływ na ludzi, nie tylko młodych, i stają się elementem codzienności czy tematem rozmów. Przenikają do świata rzeczywistego (np. za pośrednictwem języka), a co za tym idzie - kształtują ludzkie postrzeganie świata, zachowanie czy język, jakim się posługujemy. Wszystko to powoduje, że stają się niezwykle interesujące i atrakcyjne dla badacza. Może on pochylić się nad czymś nowym, co nie było dotychczas poddawane analizie, a jednocześnie zbadać zjawiska, które właśnie mają miejsce i wpływają na rzeczywistość.

Jednak w opisanej sytuacji badacz staje przed dylematem - jaką metodę badawczą wybrać? W takim przypadku należy przeanalizować dostępne narzędzia i odpowiedzieć sobie na pytania: czy są one wystarczające, czy należy je przekształcić, czy może stworzyć zupełnie nowe.

Celem dalszych rozważań jest ukazanie wypracowanej przez Marię Wojtak metodologii z zakresu genologii lingwistycznej, która w mojej ocenie doskonale sprawdzi się w opisie komentarza e-sportowego jako nowego gatunku medialnego.

\section{Genologia lingwistyczna - pojęcie gatunku}

Nie sposób mówić o genologii lingwistycznej bez refleksji nad pojęciem gatunku i jego rozumieniem w obrębie tej dyscypliny. Oddziałują na nie między innymi wczesne koncepcje pojęcia gatunku, a przede wszystkim ta sformułowana przez Michaiła Bachtina (1986, s. 348-402). Jego podstawowe tezy badawcze Danuta Ostaszewska przedstawiła następująco:

1. „u podstaw każdej wypowiedzi leżą reguły gatunkowe (i dotyczą również języka potocznego) (...); 
2. we wszystkich obszarach zastosowania języka istnieją specjalne względnie trwałe typy takich wypowiedzi - nazwane genrami (gatunkami mowy);

3. reguły gatunkowe uzależnione są od kontekstu (...);

4. wzorce (skonwencjonalizowane formy) działania językowego odnoszą się do kompetencji użytkowników języka, są zatem wspólne wszystkim członkom danej społeczności, gatunki mowy bowiem (...) są nam dane niemalże w taki sam sposób jak język ojczysty, którego używamy bez trudności również przed teoretycznym opanowaniem gramatyki;

5. schemat gatunku, będąc właściwością kompetencji komunikacyjnej użytkowników danej kultury, podlega uwarunkowaniom i zmianom równolegle z rozwojem owej kultury” (Ostaszewska, 2008, s. 20).

Chociaż współcześni badacze zwracali uwagę na pewne nieścisłości w rozważaniach Bachtina (między innymi dotyczące gatunków pierwotnych i wtórnych), pewne aspekty rozwijali, z innych rezygnowali, to jednak większość postulatów została zaakceptowana przez współczesną genologię lingwistyczną.

Istnieje wiele propozycji metodologicznych wykorzystywanych w językoznawstwie przy opisie gatunków. W poszukiwaniu metody badawczej odpowiedniej do scharakteryzowania komentarza e-sportowego sięgałam po propozycje Edwarda Balcerzana (1999), Janiny Fras (2013), Bożeny Witosz (2005) oraz Marii Wojtak (2008). Za najbardziej przydatną do opisu gatunków medialnych uznałam koncepcję Wojtak stosowaną m.in. przez łódzkich badaczy: Magdalenę Pietrzak (2013) - do opisu felietonu, Ewę Szkudlarek-Śmiechowicz $(2015,2016)$ - do opisu gatunków telewizyjnych, magazynu telewizyjnego, telenoweli paradokumentalnej, Beatę Grochalę (2016) - do opisu komentarza sportowego. Swój wybór uzasadnię poniżej, przedstawiając tę metodę oraz dokonując wstępnej analizy komentarza e-sportowego przy jej użyciu.

Maria Wojtak swoją koncepcję metodologiczną przedstawiła w monografii Gatunki prasowe (2004) oraz w wielu późniejszych artykułach (m.in. 2006; 2008). Autorka proponuje, by w badaniach genologicznych przeanalizować, jak określony tekst realizuje wzorzec gatunkowy. Tworzą go cztery aspekty:

1. „Określona struktura (model kompozycyjny), a więc rama tekstowa, podział na segmenty, relacje między segmentami - aspekt strukturalny;

2. Uwikłania komunikacyjne: obraz nadawcy i odbiorcy, cel komunikatu (potencjał illokucyjny), kontekst życiowy gatunku, a więc prymarne zastosowanie komunikacyjne - aspekt pragmatyczny; 
3. Tematyka i sposób jej przedstawienia (perspektywa, punkt widzenia, hierarchia wartości; i inne składniki obrazu świata) - aspekt poznawczy;

4. Wyznaczniki stylistyczne (cechy uwarunkowane strukturalnie, zdeterminowane pragmatycznie i związane z genezą użytych środków) - aspekt stylistyczny" (Wojtak, 2008, s. 354).

Autorka zauważa także, iż obecnie gatunki ulegają przeobrażeniom, a wzorce gatunkowe mają wiele wariantów. Wzorzec gatunkowy, według Wojtak, mieści w sobie trzy kategorie:

1. „Wzorzec kanoniczny - decydujący o tożsamości gatunku i obejmujący określoną gamę wyznaczników strukturalnych, pragmatycznych i stylistycznych;

2. Wzorce alternacyjne - takie, które funkcjonują jako rezultat przekształcania poszczególnych poziomów i aspektów wzorca kanonicznego (...);

3. Wzorce adaptacyjne - nawiązania do obcych schematów gatunkowych" (Wojtak, 2008, s. 356).

Analizując poszczególne aspekty tekstu, możemy więc wykazać, czy mamy do czynienia z tekstem o cechach kanonicznych (realizacją wzorca), czy z pewną wariancją gatunkową (reprezentacją wzorca lub okazem).

Maria Wojtak (2006) zwróciła również uwagę na to, że gatunki medialne są niejednorodne i stanowią komunikaty wieloskładnikowe. W tym przypadku mówi się niekiedy o hipergatunkach, hybrydach gatunkowych czy gatunkach złożonych. Wojtak przedstawia odmienną propozycję, wprowadzając pojęcia gatunku w formie kolekcji oraz kolekcji gatunków.

Gatunek w formie kolekcji jest gatunkiem złożonym, który:

- „składa się z gatunków trwale współwystępujących,

- ma strukturalne i funkcjonalne zwieńczenie (wyraźną ramę delimitacyjną),

- $\quad$ tworzy kompozycyjną całość" (Wojtak, 2006, s. 145).

Gatunek w formie kolekcji jest strukturą wieloelementową. Składa się z różnych gatunków, które tworzą w jego obrębie spójną dla odbiorcy całość. Kolekcja gatunków natomiast jest zgromadzeniem w jednym miejscu (na przykład w jednym numerze czasopisma) kilku tekstów reprezentujących różne gatunki, które to teksty jednak nie są trwale ze sobą związane ani nie mają kompozycyjnego zwieńczenia (ramy delimitacyjnej). Za gatunki w formie kolekcji należałoby więc uznać 
np. gatunki telewizyjne, takie jak magazyny (publicystyczny, sportowy, telewizji śniadaniowej), a także opisywany przez B. Grochalę (2016) telewizyjny komentarz sportowy.

Komentarz sportowy jako element telewizyjnej transmisji sportowej

Beata Grochala (2016) w swojej książce zaadaptowała metodę badań genologicznych Marii Wojtak, która pozwala na klarowny opis gatunku, jakim jest komentarz sportowy, oraz na pokazanie jego podstawowych cech gatunkowych.

Grochala dokonuje analizy telewizyjnej transmisji sportowej w dwóch aspektach: szerokim i wąskim. „W ujęciu szerokim jest to cała struktura programu telewizyjnego (...) w skład którego wchodzi m.in. transmisja z komentarzem/relacją z zawodów, rozmowa telewizyjna (...) dyskusje, komentarze, wywiady itp. W ujęciu wąskim to jedynie transmisja z komentarzem/relacją (...)” (Grochala, 2016, s. 94).

Poniżej przedstawię wnioski Grochali płynące $\mathrm{z}$ analizy telewizyjnej transmisji sportowej w ujęciu wąskim, w której zasadnicze miejsce zajmuje komentarz sportowy, co pozwoli mi później na porównanie go z komentarzem e-sportowym.

\section{Aspekt strukturalny}

Pod względem strukturalnym komentarz jest ściśle uzależniony od budowy samego meczu piłkarskiego. Schematycznie elementy kompozycyjne telewizyjnego komentarza meczu piłki nożnej przedstawia poniższa tabela:

\begin{tabular}{|c|c|}
\hline \multicolumn{2}{|c|}{ PIERWSZA POKOWA MECZU } \\
\hline SEGMENT INICJALNY: & $\begin{array}{l}\text { - } \quad \text { powitanie wraz z przedstawieniem się } \\
\text { komentatora i towarzyszącego mu zwykle } \\
\text { eksperta; } \\
\text { - } \text { wprowadzenie (wymienienie drużyn grają- } \\
\text { cych po obu stronach, przypomnienie, w ra- } \\
\text { mach jakich rozgrywek odbywa się mecz); } \\
\text { - podanie składów drużyn, wymienienie za- } \\
\text { wodników i ich pozycji. }\end{array}$ \\
\hline \multicolumn{2}{|l|}{ RELACJA WŁAŚCIWA } \\
\hline SEGMENT FINALNY: & $\begin{array}{l}\text { - } \quad \text { krótkie podsumowanie pierwszej części me- } \\
\text { - } \quad \text { czu; } \\
\text { - } \quad \text { „przanie wyniku; } \\
\text { [Zazwyczaj między podsumowaniem a krótką roz- } \\
\text { mową w studiu następuje blok reklamowy (który po- } \\
\text { jawia się zwykle także po zakończeniu rozmów w stu- } \\
\text { diu, a przed rozpoczęciem drugiej połowy meczu)]. }\end{array}$ \\
\hline
\end{tabular}




\begin{tabular}{|c|c|}
\hline \multicolumn{2}{|c|}{ DRUGA POKOWA MECZU } \\
\hline SEGMENT INICJALNY: & $\begin{array}{l}\text { - } \quad \text { ponowne podsumowanie pierwszej połowy } \\
\text { - } \text { peczu; } \\
\text { - podanie wyniku; } \\
\text { ponowne podanie składów. }\end{array}$ \\
\hline \multicolumn{2}{|l|}{ RELACJA WLAŚCIWA } \\
\hline SEGMENT FINALNY: & $\begin{array}{l}\text { - } \quad \text { podsumowanie całego spotkania; } \\
\text { - } \quad \text { podanie ostatecznego wyniku; } \\
\text { - } \quad \text { stawienie się; } \\
\text { [Ostatni element segne sidzami i ponowne przed- } \\
\text { tować jak koniec telewizyjnej transmisji sportowej } \\
\text { w ujęciu wąskim]. }\end{array}$ \\
\hline
\end{tabular}

Tabela 1. Elementy kompozycyjne telewizyjnej transmisji meczu piłki nożnej (w ujęciu wąskim) Źródło: Opracowanie własne (na podstawie: Grochala, 2006, s. 91-137)

Aspekt pragmatyczny - relacje nadawczo-odbiorcze

Beata Grochala, odwołując się do pracy Tomasza Gobana-Klasa (2006), dzieli odbiorców telewizyjnej transmisji sportowej na widownię, czyli tych, którzy w danym momencie wybierają i oglądają wydarzenie sportowe, oraz publiczność, czyli widzów telewizyjnych w ogóle, którzy potencjalnie mogą stać się odbiorcami danego wydarzenia sportowego.

Wśród nadawców badaczka wyróżnia dziennikarza-komentatora i eksperta. Pierwszy z nich ma za zadanie przede wszystkim zrelacjonować wydarzenia z boiska, bez ich interpretacji i oceniania zachowań poszczególnych zawodników. Z kolei do roli eksperta w telewizyjnej transmisji sportowej najczęściej powołuje się byłych zawodników lub trenerów danej dyscypliny. Oczekuje się więc od nich wiedzy i doświadczenia sportowego. Nie mają oni zwykle przygotowania dziennikarskiego, co wpływa na formę ich wypowiedzi, jednak w tym przypadku najistotniejsza jest rzetelna diagnoza sytuacji na boisku, więc poprawność językowa staje się kwestią drugorzędną. Pierwotnie zapraszanie ekspertów do komentowania miało skutkować określonym podziałem ról: zadaniem dziennikarza było opisywać to, co działo się na boisku, a eksperta - oceniać, interpretować, „dawać rady” zawodnikom. Taki podział nie funkcjonuje jednak w praktyce; często w rolę oceniającego, interpretatora wciela się sam dziennikarz. 


\section{Aspekt poznawczy}

Grochala nie przedstawia osobno poznawczego aspektu komentarza, jednak jego elementy są uwidocznione przy opisywaniu innych aspektów gatunku (por. np. aspekt strukturalny i tab. 1). Tematyką jest oczywiście w tym przypadku mecz piłkarski i jego przebieg. Jednak ze względu na to, że wśród odbiorców transmisji sportowych są nie tylko wielbiciele danej dyscypliny, lecz także czasami przypadkowa publiczność, stacje telewizyjne starają się wprowadzać do komentarza elementy niezwiązane bezpośrednio z rozgrywką, które mogą się wydać interesujące dla przeciętnego widza ${ }^{2}$. W związku z tym pojawiają się informacje dotyczące „ciekawostek z życia znanych piłkarzy, szczegóły związane z zakwaterowaniem podczas zawodów, diety, finansów itp." (Grochala, 2016, s. 142).

Istotnym elementem aspektu poznawczego każdego gatunku o wyraźnym nacechowaniu aksjologiczno-emotywnym jest wartościowanie. Wyrażona wprost aksjologizacja stanowi cechę konstytutywną każdego komentarza, a więc nie może jej zabraknąć w komentarzu sportowym. Dziennikarz oraz ekspert oceniają zjawiska obserwowane na boisku oraz zachowania zawodników, często wyraźnie faworyzując jedną z drużyn. Stronniczość ocen jest wręcz pożądana przez widzów, gdy dziennikarz wraz z ekspertem komentują mecze reprezentacji Polski lub międzynarodowe rozgrywki ligowe z udziałem polskich drużyn. Komunikacyjna rola dziennikarza lub eksperta łączy się bowiem z rolą kibica, co ma swoje odzwierciedlenie w przekazie werbalnym.

\section{Aspekt stylistyczny}

Jedną z najistotniejszych cech stylistycznych komentarza sportowego jako elementu telewizyjnej transmisji sportowej jest emocjonalność, związana z osobistym stosunkiem do wydarzeń na boisku. Kolejne cechy stylistyczne ukazane przez Grochalę to potoczność, leksyka żargonowa i specjalistyczna, błędy językowe typowe dla polszczyzny mówionej. Szybkie tempo mówienia nasila występowanie błędów, uproszczeń, powoduje eliptyczność wypowiedzi. Istotnym elementem jest także idiolekt komentatora czy dziennikarza, który wpływa na stylistyczny kształt wypowiedzi.

\section{Komentarz e-sportowy}

Materiał do analizy komentarza e-sportowego pochodzi z 20 meczów turniejowych Counter Strike: Global Offensive z udziałem polskiego zespołu Virtus.pro. Transmisje

2 Tu określenia „widz” używam w znaczeniu potocznym - „widz”, inaczej „oglądający”. 
wraz z komentarzem dostępne są w portalu YouTube. Cytowane przykłady pochodzą $\mathrm{z}$ pięciu reprezentatywnych dla gatunku realizacji ${ }^{3}$ :

- Virtus.pro vs dignitas [dalej VP:D], 18.09.2016;

- $\quad$ G2 Esports vs Virtus.pro [dalej G2:VP], 29.03.2016;

- Virtus.pro vs Natus Vincere [dalej VP:NaVi], 29.08.2015;

- Virtus.pro vs Team Kinguin [dalej VP:TK], 23.09.2016;

- $\quad$ Ninjas in pyjamas vs Virtus.pro [dalej NIP:VP], 28.04.2014.

\section{Aspekt strukturalny}

Segment inicjalny komentarzy meczów CS stanowi wprowadzenie, w którym podaje się nazwy drużyn, nazwę mapy oraz nazwę turnieju i jego etapu. W odróżnieniu od komentarza sportowego zazwyczaj komentator nie przedstawia się przed rozpoczęciem meczu. Wynika to z faktu, iż zwykle mecz wraz z komentarzem można oglądać na kanale należącym do konkretnego komentatora, zatem nie ma potrzeby przedstawiania się własnym widzom. Często także komentowany mecz jest częścią transmisji na żywo trwającej jakiś czas już przed jego rozpoczęciem i po zakończeniu, w związku z czym komentator de facto nie wita się z odbiorcami, np.:

„Mapa de_overpass. Tej mapy na tym turnieju chyba jeszcze nie było ani razu, tak że najwyższa pora zagrać overpassa $w$ półfinale DreamHacka Zowie Bucharest dwa tysiące szesnaście. Virtus.pro kontra Dignitas. Mapa decydująca, ostateczne starcie (...). Nasi po stronie antyterrorystów (...)” [VP:D].

Dalej następuje relacja właściwa, podczas której komentator analizuje i ocenia zjawiska obserwowane na ekranie komputera, np.:

„Są cztery akacze po stronie antyterrorystów, nasi już oczywiście na fullu, chociaż pashaBiceps tylko z magiem. Teraz ważne, żeby tę rundę wygrać (...). Już tracimy snacksa. PashaBiceps tymczasem schowany za smołkiem, już zobaczył rywala, próbuje go skrócić, no i niestety... Jak już nie trafił na początku, trzeba było uciekać, bo MagicksbOY miał tu już przewagę, wiedział dokładnie, gdzie jest rywal. Pasha nie miał szans (...)" [VP:D].

3 Wszystkie cytaty pochodzą z meczów dostępnych w portalu YouTube, na prywatnym kanale Piotra „Izaka” Skowyrskiego - izak LIVE, https://www.youtube.com/user/issacc87 [data dostępu: 22.08.2017]. 
Kolejnym elementem jest segment finalny pierwszej połowy spotkania, w którym komentator podsumowuje tę część meczu i podaje wynik. Inaczej niż w komentarzu sportowym, czas między pierwszą a drugą połową spotkania to zaledwie dwie, trzy minuty. Czasami są one wypełnione reklamami odtwarzanymi przez samego komentatora. Jednak jeśli nie włączy on bloku reklamowego, musi sam wypełnić czas, na przykład analizą pierwszej połowy meczu, przypomnieniem emocjonujących momentów etc., łączy więc funkcję eksperta i komentatora (por. analizę aspektu pragmatycznego w dalszej części artykułu), np.:

„Tak się kończy pierwsza połówka, oczywiście nasi prowadzą, no ale ważna będzie pistoletówka. Pierwszą przegraliśmy, później wygraliśmy rundę eko, kiedy z tezetki Byali zdobył dwa fragi, później jednego Taz, później nasi poginęli, ale Neo z kolei odpowiedział, no i było dwóch na jednego (...). No i to jeszcze nie są dobre humory, mogłyby być lepsze te humory po stronie Virtus.pro, no ale niestety, gra Dignitas dzisiaj (...), nie jest łatwo naszym walczyć z duńską formacją. Są skoncentrowani, chcą walczyć (...)” [VP:D].

Drugą połowę meczu rozpoczyna krótka informacja o jej początku, np.:

„Czekamy na start drugiej połówki, a ta już się nam rozpoczyna. Pięć kevlarów po stronie antyterrorystów. U nas trzy kevlary i są też granaty Neo i Taz, a więc coś przygotujemy taktycznego (...)" [NIP:VP].

Dalej następuje relacja właściwa. Z uwagi na krótki czas pomiędzy segmentami nie ma potrzeby ponownego przypominania drużyn czy dotychczasowego wyniku.

Segment finalny najczęściej składa się z podsumowania ostatnich minut i całego meczu, podania ostatecznego wyniku i pożegnania z widzami, jeśli koniec meczu oznacza koniec transmisji na kanale komentatora, np.:

„Taz jakby coś kombinował, sprawdzi chyba sobie tę pozycję, Edward tylko na to czeka, Edward ma też kałacha, no i zobaczmy: Taz! Nie da rady. Szesnaście - cztery i to jest koniec. To jest koniec, Virtusi na kolanach w tym meczu. Kompletnie zniszczeni przez zespół Natus Vincere (...). Virtusi zagrali fatalnie (...). No i zaraz sobie zobaczymy wywiady pomeczowe (...)" [VP:NaVi]. 
W powyższym przykładzie komentator krótko podsumował wynik meczu i poziom gry polskiego zespołu, a następnie wyświetlił na ekranie wywiady przeprowadzane po meczu z zawodnikami (są one także stałym elementem telewizyjnej transmisji sportowej). Warto przy tym zauważyć, iż segment finalny całego meczu jest najmniej usystematyzowanym elementem struktury komentarza e-sportowego. $\mathrm{Z}$ względu na ogromne niekiedy emocje towarzyszące komentatorowi oraz brak obwarowań czasowych, jakie występują w telewizji, w przypadku zwycięstwa polskiej drużyny segment finalny składa się czasami z okrzyków radości i niedowierzania, co sprawia, że komentujący nie podsumowuje całego spotkania w usystematyzowany sposób, np.:

„Neo będzie jednak walczył, zajął sobie dobrą pozycję, może tutaj próbować. Smołk na schody, jest MagicksbOY. Świetnie Neo, jeden na dwóch, Neo, jeszcze walczy, jeszcze próbuje (...), konflikt na blisko. Neo po raz kolejny, Neo walczy! Neo! Jeden na jeden! Neo! Koniec! Koniec! Neo jeden na czterech w ostatniej rundzie, to jest niewiarygodne! Co ci Virtusi zrobili w tym momencie! Najpierw Byali, później Neo! Co za końcówka! Neo ratuje nam skóry po raz kolejny! Oj, to jest radość, to jest szczęście. (...) Neo jeden na czterech. Jak on to zrobił? (...) Niewiarygodne! Legenda! Polska legenda Counter Strike'a! (...)” [VP:D].

Po tym zakończeniu komentator również pokazał na swoim ekranie wywiady z zawodnikami. Po ich wysłuchaniu jeszcze przez kilkanaście minut, rozentuzjazmowany, komentował koniec meczu. W takim przypadku segment finalny kończy zmiana tematu, gdyż nie mamy tu do czynienia z pożegnaniem czy wyraźnym zakończeniem.

\section{Aspekt pragmatyczny}

Odbiorcami komentarza e-sportowego w przypadku meczów Counter Strike: Global Offensive są internauci. Otwierają oni w przeglądarkach stronę internetową, na której znajduje się kanał danego komentatora. Główny model odbioru komentarzy e-sportowych stanowi oglądanie meczu na żywo w portalu Twitch.tv, możliwe jest jednak również obejrzenie meczu w portalu YouTube, gdzie znajdują się udostępnione przez komentatora transmisje meczów, które już się odbyły.

Istnieje kilka ważnych różnic o podłożu pragmatycznym pomiędzy komentarzem e-sportowym a sportowym. Jedną z nich jest fakt, że w przypadku tego pierwszego 
odbiorcami są niemal wyłącznie kibice danej dyscypliny e-sportowej, którzy świadomie wchodzą na określoną, znaną w ich środowisku stronę, by móc kibicować wybranej drużynie. Niewielkie jest prawdopodobieństwo, że osoba niezainteresowana e-sportem trafi na taką transmisję. Należy także zwrócić uwagę na bardzo ważny element odróżniający tradycyjną transmisję sportową od transmisji komentarzy e-sportowych, jakim jest partycypacja odbiorców. W portalu Twitch.tv podczas oglądania meczu widzowie poprzez czat mają możliwość odnoszenia się do obserwowanych wydarzeń, reagowania na zachowania graczy czy wypowiedzi komentatora. Wielokrotnie również sam komentujący odnosi się do takich wiadomości, popierając je lub negując. Czat doskonale oddaje też poziom emocjonalny widzów. Dzięki temu komentator może podejmować działania, które mają na celu uatrakcyjnienie przekazu, pobudzenie widzów i zwiększenie ich zaangażowania. Ponadto jeśli widzowie są usatysfakcjonowani komentarzem, mogą docenić komentatora nie tylko wypowiedzią na czacie, lecz także tak zwanymi donate’ami, czyli przelewami pieniężnymi na jego konto. Zatem im lepszy komentarz i im więcej działań pobudzających i uaktywniających odbiorcę, tym większy zysk (także finansowy) dla komentującego.

$\mathrm{Na}$ polskiej scenie e-sportowej wiodącym nadawcą komentarza e-sportowego jest Piotr „Izak” Skowyrski. Kiedy rozpoczynał komentowanie, nie był ani dziennikarzem, ani zawodowym graczem CS. Wygrał casting organizowany przez telewizję internetową HeadShot TV, dla której komentował pierwsze mecze CS. Później założył własny kanał i zaczął zajmować się nim profesjonalnie. Wynika z tego, że komentatorem e-sportowym może stać się każdy, kto dobrze zna daną dyscyplinę i komu uda się uzyskać akredytację organizatorów danego wydarzenia e-sportowego. Coraz częściej zdarza się, że zawody e-sportowe są transmitowane przez sportowe kanały telewizyjne, i wtedy nadawcą jest dziennikarz związany z daną stacją. Powoduje to jednak znaczne obniżenie jakości komentarza, gdyż najczęściej osoba komentująca nie zna się dobrze na e-sporcie. Takie transmisje nie cieszą się też dużą popularnością.

Nadawca w przypadku komentarza e-sportowego łączy w sobie rolę komentatora i eksperta. Jest to zazwyczaj osoba, która doskonale zna daną dyscyplinę, więc nie tylko relacjonuje wydarzenia obserwowane na ekranie, lecz także przewiduje zachowania zawodników czy „sugeruje im” określoną taktykę. Może sobie na to pozwolić również z tego względu, że odbiorcy świadomie wybierają właśnie jej komentarz, więc ufają jej opinii.

Warto zwrócić uwagę na fakt, iż komentator podczas transmisji jest stale widoczny dla odbiorców. Na ekranie znajduje się małe „okienko”, w którym widać jego postać. Z tego powodu na przekaz wpływają nie tylko środki werbalne, lecz także nie- 
werbalne, jak choćby mimika twarzy czy gesty wykonywane przez komentatora. Ten element nie występuje w przypadku tradycyjnego komentarza sportowego. Wynika to prawdopodobnie z konwencji komentarzy e-sportowych, będących częścią prywatnego streamingu komentatora. Dzięki temu odbiorcy mają osobisty stosunek nie tylko do rozgrywki, lecz także do komentującego.

\section{Aspekt poznawczy}

Tematem komentarzy e-sportowych są mecze rozgrywane w określonych dyscyplinach e-sportu. W przypadku CS komentator skupia się przede wszystkim na takich aspektach jak poziom gry zawodników danej drużyny, przebieg spotkania, ocena konkretnych momentów meczu, przewidywanie posunięć zawodników i ocena ich zachowań podczas gry. W przypadku komentarza e-sportowego komentator nie musi być obiektywny. Może wprost wyrażać swoje sympatie lub antypatie względem określonej drużyny. Często komentujący wprost krytykują graczy, których na przykład podejrzewa się o oszustwa podczas rozgrywek (czyli stosowanie nielegalnego oprogramowania). Czasami pozwalają sobie także na odniesienia do życia prywatnego zawodników, gratulacje z okazji ślubu lub narodzin dziecka. Ma to niewątpliwie na celu uatrakcyjnienie komentarza, jednak zdarza się znacznie rzadziej niż w przypadku telewizyjnej transmisji sportowej.

\section{Aspekt stylistyczny}

Komentarz e-sportowy wykazuje wiele podobieństw stylistycznych do komentarza sportowego, będącego elementem telewizyjnej transmisji sportowej. Jedną z jego podstawowych cech jest emocjonalność. Komentator przekazuje odbiorcy swoje uczucia związane z rozgrywką. W sposób oczywisty najbardziej nacechowane są komentarze meczów z udziałem polskiej drużyny Virtus.pro. Oto przykład takiej wypowiedzi:

„Niewiarygodne po prostu, co robią Virtusi w tym meczu! Nie wierzę w to, co się wyprawia! Virtusi wracają w wielkim stylu! (...) Wynik jeden - czternaście to mówi samo za siebie! Ten mecz będzie się zawodnikom francuskiej formacji śnić przez długie, długie lata!" [G2:VP].

Pod względem stylu komentarz e-sportowy charakteryzuje także leksyka socjolektalna, z zakresu socjolektu graczy Counter Strike: Global Offensive. Osoby, które nie znają żargonu graczy CS, niewiele zrozumieją z wypowiedzi komentującego, np. (por. także przykłady wcześniejsze): 
„Na razie nasi pędzą na długą, jest tutaj pasha, niewiele zabrakło, a trafiłby rywala. Jeszcze... jest frag od pashy, już cofa, błyskawicznie rotuje, zdobył pierwszego fraga otwierającego rundę. Dwie awupy jeszcze w rękach graczy CT" [VP:TK].

W powyższym fragmencie uwidacznia się także ważna cecha składniowa komentarzy sportowych i e-sportowych. Bardzo szybkie tempo mówienia powoduje tworzenie krótkich, urywanych niekiedy zdań, równoważników zdań, wypowiedzeń niedokończonych, a więc konstrukcji typowych dla składni emocjonalnej (por. Grzesiuk, 1995). Jest także przyczyną błędów językowych, występowania szeregu powtórzeń czy uproszczeń fonetycznych.

Komentarz e-sportowy jest również w porównaniu do sportowego znacznie bardziej potoczny. Jest to zapewne spowodowane tym, że przestrzeń internetowa nie wymaga (a wręcz nie dopuszcza) oficjalności, w przekazach internetowych dominuje więc swoboda komunikacyjna i kolokwialność, np.:

„(...) no i zobaczmy. jak to wszystko się potoczy; Pasha zdziwiony, wchodzi na rywala, pójdzie po zwycięstwo, bardzo fajnie rozegrana akcja, mamy dobrą rundę, no i tak to się wszystko kiepsko kończy, będzie ciężko, bałem się, że to będzie głupio, runda przegrana, kiwa głową Byali, że odpuścili ten bombsite” [VP:NaVi].

\section{Zakończenie}

Zaadaptowanie metodologii genologicznej Marii Wojtak do opisu komentarza e-sportowego pozwala na klarowne przedstawienie jego cech gatunkowych oraz ukazanie analogii i różnic między komentarzem sportowym i e-sportowym dzięki zastosowaniu tej samej metody. Biorąc pod uwagę fakt, że komentatorzy e-sportowi inspirowali się komentarzem sportowym, wydaje się to szczególnie istotne.

Komentarz e-sportowy jest nowym gatunkiem medialnym, który dotychczas nie doczekał się szczegółowego opisu. Funkcjonuje w sferze internetu, który również wciąż stanowi wyzwanie metodologiczne nie tylko dla językoznawców. Gry komputerowe stają się coraz ważniejszym zjawiskiem we współczesnej rzeczywistości i są nie tylko źródłem rozrywki dzieci i młodzieży, lecz także sposobem na życie i utrzymanie się dorosłych. Przestrzeń ta wciąż zmienia się i rozwija. Mimo trudności metodologicznych warto podjąć próbę jej zbadania. 


\section{Bibliografia}

Bachtin, M. (1986). Estetyka twórczości słownej. Warszawa: Państwowy Instytut Wydawniczy.

Balcerzan, E. (1999). W stronę genologii multimedialnej. Teksty Drugie, 10(6): 7-24.

Fras, J. (2013). O typologii wypowiedzi medialnych $i$ dziennikarskich. Wrocław: Wydawnictwo Uniwersytetu Wrocławskiego.

Goban-Klas, T. (2006). Media i komunikowanie masowe. Warszawa: Wydawnictwo Naukowe PWN.

Grochala, B. (2016). Transmisja telewizyjna $w$ ujęciu genologii lingwistycznej na materiale transmisji meczów piłki nożnej. Łódź: Wydawnictwo Uniwersytetu Łódzkiego.

Grzesiuk, A. (1995). Składnia wypowiedzi emocjonalnych. Lublin: Wydawnictwo UMCS.

Ostaszewska, D. (2008). Genologia lingwistyczna jako subdyscyplina współczesnego językoznawstwa. W: D. Ostaszewska, R. Cudak (red.), Polska genologia lingwistyczna (s. 11-33). Warszawa: Wydawnictwo Naukowe PWN.

Szkudlarek-Śmiechowicz, E. (2015). Magazyn telewizyjny jako gatunek w formie kolekcji. W: D. Ostaszewska, J. Przyklen (red.), Gatunki mowy i ich ewolucja (tom V: Gatunek a granice, s. 393-403). Katowice: Wydawnictwo Uniwersytetu Śląskiego.

Szkudlarek-Śmiechowicz, E. (2016). Strukturalno-stylistyczne cechy gatunku, a kształtowanie relacji nadawczo-odbiorczych w telenoweli paradokumentalnej „Szkoła”. Acta Universitatis Lodziensis. Folia Literaria Polonica, 18(2): 49-62.

Witosz, B. (2005). Genologia lingwistyczna. Zarys problematyki. Katowice: Wydawnictwo Uniwersytetu Śląskiego.

Wojtak, M. (2004). Gatunki prasowe. Lublin: Wydawnictwo UMCS.

Wojtak, M. (2006). Gatunek w formie kolekcji a kolekcja gatunków. W: Z. Krążyńska, Z. Zagórski (red.), Poznańskie Spotkania Językoznawcze (tom XV, s. 143-152). Poznań: Wydawnictwo PTPN.

Wojtak, M. (2008). Wzorce gatunkowe wypowiedzi a realizacje tekstowe. W: D. Ostaszewska, R. Cudak (red.), Polska genologia lingwistyczna (s. 353-361). Warszawa: Wydawnictwo Naukowe PWN. 


\section{Ludografia}

Hidden Path Entertainment, Valve Corporation (2012). Counter Strike: Global Offensive [gra wieloplatformowa]. USA: Valve Corporation.

Riot Games (2009). League of Legends [PC, Mac]. USA: Riot Games.

\section{Abstrakt}

Gry komputerowe są niezwykle istotnym elementem współczesnej rzeczywistości. Ich popularność przyczyniła się do powstania sceny e-sportowej, a tym samym do zaistnienia nowego gatunku medialnego, jakim jest komentarz e-sportowy. W powyższym artykule ukazuję zastosowanie w analizie komentarza e-sportowego do meczów Counter Strike: Global Offensive metody badań genologicznych autorstwa Marii Wojtak. Zgodnie z założeniami autorki metody analizuję cztery aspekty gatunkowe. Pierwszym z nich jest struktura, a więc rama delimitacyjna oraz poszczególne segmenty, z jakich składa się cały komentarz. Kolejny aspekt, pragmatyczny, dotyczy relacji między nadawcą - komentatorem a odbiorcą - internautą. Dalej konieczny jest opis aspektu poznawczego, czyli tematyki, wartościowania i innych elementów tworzących językowy obraz świata, występujący w danym gatunku. Ostatnim aspektem są cechy stylistyczne charakterystyczne dla komentarza e-sportowego, takie jak potoczność, emocjonalność czy leksyka żargonowa. Główny wniosek płynący z artykułu wskazuje na stosowność zaadaptowania metody Marii Wojtak do badań nad nowym gatunkiem medialnym, jakim jest komentarz e-sportowy.

Słowa kluczowe: genologia lingwistyczna, gatunki medialne, komentarz e-sportowy, Counter Strike: Global Offensive

\section{Abstract}

Video games are a crucial part of contemporary reality. Their popularity has contributed to the appearance of the esports scene, and thus to the emergence of a new media genre: the esports commentary. In this paper I apply Maria Wojtak's method of genological research to analyze the esports commentary to the game sessions of Counter Strike: Global Offensive. In accordance with the author's premises I examine four genre aspects. The first is structure, i.e., the delimitative framework as well as particular segments which make up the entire commentary. The next aspect, the prag- 
matic one, concerns the relationship between the addresser (commentator) and the addressee (Internet user). What is also needed is a description of the cognitive aspect, i.e., subject matter, valuation, and other elements of the genre's lingual image of the world. The final aspect is the characteristic stylistic traits of the esports commentary, such as its colloquial nature, its emotionality, or its jargon vocabulary. The main conclusion of the paper is that it is suitable to adapt Maria Wojtak's method to the research into esports commentary as a new media genre.

Keywords: linguistic genology, media genres, esports commentary, Counter Strike: Global Offensive

Autorka

mgr Martyna Rzeźnik (rzeznik.martyna@gmail.com) - doktorantka w Zakładzie Współczesnego Języka Polskiego Uniwersytetu Łódzkiego, przewodnicząca Koła Naukowego Językoznawców, pracę magisterską Komentarz e-sportowy jako nowy gatunek medialny na podstawie meczów Counter Strike: Global Offensive napisała w Zakładzie Współczesnego Języka Polskiego. Jej zainteresowania naukowe dotyczą przede wszystkim języka współczesnych mediów. 